\title{
Examining the effects of computer-assisted preschool educational activities on children's intuitive mathematical ability
}

\author{
F. Ülkü Yildiz 1, ${ }^{*}$, Gökhan Kayili ${ }^{2, *}$ \\ 1,2 Department of Child Development-Faculty of Health Sciences-Selçuk University, Selçuklu, \\ Konya, Turkey
}

\section{Keywords:}

Computer-assisted activity Preschool education Intuitive mathematical ability

Received: 28 February 2015

Accepted: 13 July 2015

Published: 15 October 2015

\begin{abstract}
This study aims to examine the effects of computer-assisted preschool educational activities on children's intuitive mathematical ability. The group under investigation consists of randomly selected five-year-old children attending a nursery school in Selçuklu county, Konya, Turkey, during 2011-2012. The research is designed to have pre-test and post-test models with a control group. A total of 40 children (20 children in an experimental group and 20 children in the control group) are observed. The Intuitive Mathematical Ability (IMA) test is conducted to determine children's intuitive mathematical ability. In particular, the test is administered before and after the experiments. The Mann-Whitney U-test is taken to analyze data emerging from those tests. In general, the results indicate that computer-assisted preschool educational activities have made a positive contribution to the intuitive mathematical ability of five years old children. Hence, computer-assisted preschool educational activities may have a promising potential to be integrated with a preschool education program.
\end{abstract}

(C) 2015 The Author. Published by TAF Publishing.

\section{INTRODUCTION}

The current study attempts to discuss the topic being investigated as a thoughtful set of multidisciplinary understandings. The first element includes the concept of intuition. An intuition refers to a sudden insight of a means, indicating the critical importance or structure of a problem or situation without resorting to logical reasoning (Güven, 2007). According to Yıldırım (1996), intuition is defined as the ability to reach knowledge directly and neither through an observation nor any interference. Piaget (1972) has found that the age between four to seven years old as an intuitive period for children. During

\footnotetext{
*Corresponding author: F. Ülkü Yildiz

E-mail: fulkuyildiz@gmail.com
} 
the period, children naturally incline to act using their intuition. In fact, children are not yet classified during the period, while any conservation has not yet developed. Children intuitively focus on the remarkable property of an object and may overlook other details. Then, any children may not be able to reverse the processes (Senemoğlu, 2007).

Next, the second element includes the intuitive math. It is one of the four basic philosophies of math. In fact, intuition may have taken place on the first basis of mathematical thinking of preschool children. In particular, early experiences acquired over an object may depend on a child's perceptual development (Güven, 2001). Some researchers have suggested that intuitive thinking has many positive effects on education, especially in mathematics. It shall start by helping a child to notice the power of one's intuition, while intuitive mathematics-related practices are conducted. Intuitive thinking may enhance the success of numerical problems and strengthen problem-solving processes. Besides, it helps to detect relationships in a quick and clear way (Dixon and Moore, 1996; Farnham-Diggory, 1972).

Then, the third component includes computer-assisted learning and training technology. In the 21st century, technological tools, e.g. computers, tablets, smart boards have a lot of potential to support children in finishing tasks requested by educational materials. In particular, rapid stimulus and instant results of these materials and the inability of corporal punishment are considerably a result of the use of technologies by children and educators. For example, a question whether children requires smart board in preschool or not is being discussed. Using smart boards means to use visual, auditory, motor and communication skills together alongside the embedded touch feature besides other educational technologies (Altınçelik, 2009). Researches have shown that it may be useful for children to use technologies such as computers in a developmentally appropriate way, and should not be abused by any means (Haugland, 2004). By using computers and smart boards, children may learn numbers, shapes, colors, variety of sounds and many other concepts, while finding an opportunity to develop their skills, e.g. compare-and-contrast, counting, addition and subtraction. Their language skills may also be developed by re-telling stories they have heard from computers, a continuous use of words to increase their vocabulary, and by using drawing and painting programs to develop their motor skills. Computers and smart boards may have encouraged children's problem solving skills and their direct use over concrete objects. In 48 short, they may offer children a variety of thinking stimuli (Aktaş-Arnas, 2005).

Furthermore, there is an emphasis to effectively use computers in mathematics education once children start school. In particular, a 10-20 minutes daily computer support has been found to provide significant benefits for children. Prior studies conducted over younger children have shown that educational elements are easily learned with the help of computers. Besides, researches have suggested whenever mathematics education in kindergarten is supported with the use of computers, children have been more skilled. They have also suggested that a computer-aided education in kindergarten may have been causing an increase in children's spatial perception, geometric thinking and problem-solving skills (Clements, 1987; Clements, 2002). In addition, the most important advantage of computer-assisted learning appears in its 
capability to turn abstracts into concrete concepts, and any learning activity is therefore quicker and more meaningful (Efendioğlu, 2006).

Moreover, the current research has a particular objective to examine the effects of computer-assisted preschool educational activities on children's intuitive mathematical ability. The study hence aims at answering these following research questions in accordance with the objective:

(i) After an intervention, is there any significant difference between the average scores of the Intuitive Mathematical Ability (IMA)-based Test concept of weight within the experimental and control groups?

(ii) After an intervention, is there any significant difference between the average test scores of the IMA-based Test concept of quantity in the groups?

(iii) After an intervention, is there any significant difference between the average test scores of the IMA Test concept of size in the experimental and control groups?

TABLE I. Descriptive statistics for children under observation

\begin{tabular}{llcccc}
\hline \hline & & \multicolumn{2}{c}{ Experimental Group } & \multicolumn{2}{c}{ Control Group } \\
\cline { 3 - 6 } & & $\mathbf{n}$ & $\mathbf{\%}$ & $\mathbf{n}$ & $\mathbf{\%}$ \\
\hline \multirow{3}{*}{ Gender } & Girls & 9 & 45 & 6 & 31.6 \\
& Boys & 11 & 55 & 13 & 68.4 \\
\cline { 2 - 6 } & Total & 20 & 100 & 19 & 100 \\
\hline Socio- & Low $(0-1000 \mathrm{TL})$ & 5 & 25 & 6 & 35 \\
economic & Middle (1001-3000 TL) & 11 & 55 & 9 & 45 \\
status & High (3001 - ... TL) & 4 & 20 & 5 & 25 \\
\hline \hline
\end{tabular}

\section{METHOD}

\section{Research Design}

This research is experimental, and designed to include both pre-test and posttest models with a control group. It is considered as a classic controlled experimental design with a randomized pre-test/post-test design.

\section{Research Group}

The group under investigation consists of 40 randomly-selected five years old children attending Melikşah Nursery School in Selçuklu county of Konya in Turkey during 2011-2012 school year. Twenty children are included in the experimental group, while the rest are in the control group. Furthermore, a descriptive statistics for the children includes gender and socio-economic status (Table 1). Looking at the table, the experimental group consists of 9 girls (45\%) and 11 boys (55\%). In terms of socio-economic, the groups includes 5 children from low income families (25\%), 11 from middle income (55\%) and 4 from high income ones (20\%). In the control group, 6 children are girls (31.6\%) and 13 are boys (68.4\%). In terms of socio-economic status, 6 children in the control group come from low income families (35\%), 9 from middle income (45\%) and 5 from high income ones (25\%). All children are normally developed and have gone through an earlier education at independent kindergarten classes.

\section{Research Instrument}


IMA Test (Güven, 2001) is taken to determine children's intuitive mathematical ability. IMA Test is an improved research instrument to measure intuitive abilities associated with mathematical concepts for 4-6 years old children. The test has a total of 35 questions. It is administered individually, 15 minutes for each child. The questions are arranged in the form of pictures or symbols. Tangible things, e.g. plastic cups, cotton, and pencil, or rounded objects, e.g. tea brand and money, are used in several questions. Mathematical questions in the test include: amount (plurality; 10 questions), size (volume; 8 questions), length (8 questions), weight (8 questions), and numerical size (1 question). Because of a younger age range, the questions are presented to make a story. The response time for each question is limited to 5 seconds. Every correct answer is marked with a plus symbol, while every incorrect one is marked with a negative. The total test score is the sum of correct responses by children to these 35 questions.

From the tests, the test-retest correlation coefficient $(n=30)$ is found at .76, while the internal consistency coefficient for all age groups $(n=200)$ is .73 . An analysis is

TABLE 2. Test results of children's intuitive mathematical ability related to pretest scores

\begin{tabular}{llcccccccc}
\hline $\begin{array}{c}\text { Intuitive } \\
\text { Mathematical } \\
\text { Ability Test }\end{array}$ & \multicolumn{1}{c}{ Group } & $\mathbf{N}$ & $\overline{\mathbf{X}}$ & $\mathbf{S}$ & $\begin{array}{c}\text { Mean } \\
\text { Rank }\end{array}$ & $\begin{array}{c}\text { Sum of } \\
\text { Ranks }\end{array}$ & $\mathbf{U}$ & $\mathbf{z}$ & $\mathbf{p}$ \\
\hline \multirow{2}{*}{ Weight } & Experimental & 20 & 3.41 & .50 & 16.38 & 278.50 & 125.50 & -.68 & .497 \\
& Control & 20 & 3.52 & .51 & 18.62 & 316.50 & & & \\
\hline \multirow{2}{*}{ Quantity } & Experimental & 20 & 4.82 & .50 & 18.68 & 317.50 & 124.50 & -.712 & .477 \\
& Control & 20 & 4.48 & .36 & 16.32 & 277.50 & & & \\
\hline \multirow{2}{*}{ Size } & Experimental & 20 & 3.52 & .44 & 19.18 & 326.00 & 116.00 & -1.008 & .314 \\
& Control & 20 & 3.05 & .50 & 15.82 & 269.00 & & & \\
\hline \hline
\end{tabular}

conducted on the relationship between the Early Mathematics Ability (EMA) Test-2 to determine criterion validity, in which Pearson's product-moment correlation coefficient $(\mathrm{n}=32)$ is found at .84 . Practically, children's weight, quantity and size in math-related fields are taken to compare intuitive math skills during the field test.

\section{Process}

Before an intervention, IMA Test is administered to the groups. In an intervention process (experimental transaction), children within the experimental group get a preschool education through computer-assisted preschool educational activities and Preschool Education Program (PEP) by the Turkish Ministry of Education. On the other hand, children in the control group get a preschool education through PEP only. Children in the experimental and control groups are selected from the same school and with the same economic condition. The intervention takes a total of eight weeks. Children in the experimental group attend the process two days in a week. After the 
experimental transaction process, IMA Test is administered over 124 the groups, and the scores are compared between these groups.

\section{Data Analysis}

Furthermore, the data are analyzed by using the Mann-Whitney's U-Test. The UTest is taken to test whether points obtained from these two unrelated groups significantly differ each other or not. In the research, the significance of differences between the point averages is tested at .05 level of significance.

\section{RESULTS AND FINDINGS}

Table 2 exhibits the results of IMA Test by children within experimental and control groups related to the pretest scores. The tables indicates an insignificant statistical difference between experimental and control groups in terms of their scores from IMA-based subtests (weight at $U=125.50, p>.05$; quantity at $\mathrm{U}=124.50, p>.05$; and size at $\mathrm{U}=116.00, \mathrm{p}>.05$ ). If mean ranks, sum of ranks and arithmetic means are considered, children who have received a preschool education in an early childhood period with computer-assisted preschool educational activities (experimental group) have equivalent IMA Test scores compared to those with the PEP only (control group) during their early childhood period. It indicates that the groups are identical to each other prior to the experimental process.

TABLE 3. Test results of children's intuitive mathematical ability related to posttest scores

\begin{tabular}{llcccccccc}
\hline \hline $\begin{array}{c}\text { Intuitive } \\
\begin{array}{c}\text { Mathematical } \\
\text { Ability Test }\end{array}\end{array}$ & \multicolumn{1}{c}{ Group } & $\mathbf{N}$ & $\overline{\mathbf{X}}$ & $\mathbf{S}$ & $\begin{array}{c}\text { Mean } \\
\text { Rank }\end{array}$ & $\begin{array}{c}\text { Sum of } \\
\text { Ranks }\end{array}$ & $\mathbf{U}$ & $\mathbf{z}$ & $\mathbf{p}$ \\
\hline \multirow{2}{*}{ Weight } & Experimental & 20 & 5.23 & .44 & 21.12 & 359.00 & 83.000 & -2.180 & $.020^{*}$ \\
& Control & 20 & 4.05 & .30 & 13.00 & 236.00 & & & \\
\hline \multirow{2}{*}{ Quantity } & Experimental & 20 & 7.88 & .30 & 25.00 & 425.00 & 17.000 & -4.450 & $.000^{*}$ \\
& Control & 20 & 4.88 & .44 & 10.00 & 170.00 & & & \\
\hline \multirow{2}{*}{ Size } & Experimental & 20 & 4.76 & .41 & 22.00 & 374.00 & 68.000 & -2.697 & $.007^{*}$ \\
& Control & 20 & 3.41 & .48 & 13.00 & 221.00 & & & \\
\hline \hline Note: ${ }^{*} \mathrm{p}<.05$ & & & & & & & & &
\end{tabular}

In Table 3, the results of IMA Test by children in these two groups related to their posttest scores are provided. According to the table, there is a significant statistical difference between experimental and control groups in terms of their scores from subtests of IMA Test (weight at $U=83.000, \mathrm{p}<.05$; quantity at $\mathrm{U}=17.000, \mathrm{p}<.05$; and size at $\mathrm{U}=68.000, \mathrm{p}<.05)$. When mean ranks, sum of ranks and arithmetic means are considered, children who get a preschool education with the support of computer assisted preschool educational activities (experimental group) have higher IMA Test scores compared to ones who receive a preschool education with PEP only (control group) in the early childhood period. It indicates that the post-test mean scores of intuitive 
mathematical ability (weight, quantity, size) between the groups show a statistically-significant difference in favor of the experimental group.

Besides Piaget's proposal of four-to-seven years as the intuitive period of children (1972), Baroody (1987) has suggested that preschool math is merely a processing of intuition. Babies have even had the ability of intuitive distinctiveness (Berk and Erdoğan, 2013). For example, the appearance of a second puppet after getting used to the first one has triggered a reaction from a few-months-old baby. Despite giving no formal information, babies' reaction during a situation as such may have proven that intuitive features exist since early ages.

Furthermore, Güven (2004) has developed a family and teacher participation program on an intuitive training for five years old children, where the effectiveness of the program on children's mathematical intuition is observed. The study reveals that the program has no clear contribution to children's mathematical intuition education. However, the current study shows an increase of children's intuitive mathematical ability being observed when an intuitive mathematics education is supported with computers and smart boards. The results show that the use of smart boards and computer technology may have contributed more to learning. Preston and Mowbray (2008)'s study has also supported the current findings. They have made an emphasize on the fact that a technology-assisted education may have attracted children more than traditional methods, while children have more fun to act as groups since they feel as part of the class physically. In fact, the review of prior literature indicates that a computer-aided preschool education for children may have been increasing their cognitive abilities (Chute and Miksad, 1997) and analogical thinking skills significantly, growing their ability to understand root source of a problem (Clements, 2002), and showing a proof that it is possible to learn how to write before having able to read (Cohen, 1995). Thus, findings from the current research are clearly consistent with prior studies on information and learning technology (Gülcü, 2014; Gündoğdu, 2014; Higgins et al., 2007).

Next, Pekçağlıyan (1990) have examined several classical training methods and computer-based training programs applied to six years old preschool children. The work reveals that computer-assisted training programs are more effective in terms of numbers, geometric shapes and color tones, recognition of mental development, identification, and discrimination stages compared to education through classical training techniques. Besides, Aral and Bütün (2004) have attempted to examine the impact of computers in visual perception among 6 years old kindergarten children. According to their results, children with a computer-aided education have higher scores in terms of ground distinction, shape stability, the perception of position with the space and the perception of space relationships than those who do not get a computer-aided education. In addition, Donaldson (1992) and Akman (2002) have stated that the use of various materials in teaching mathematical concepts may have brought not only an easier understanding over the perception of mathematical, spatial and other concepts but also has made a permanent learning process for children. In the current study, preschool education environment is supported by computers and smart boards for children in the experimental group, while the control group continues to pursue routines. The findings have shown that children 
participating in computer-aided preschool activities in fact have higher intuitive math skill scores than those in the control group.

\section{CONCLUSION}

A general conclusion includes the fact that preschool children who get a preschool education with computer-assisted educational activities in their early childhood have higher intuitive mathematical ability scores compared to those who receive a preschool education with PEP only. Then, these following suggestions may act as insights for either further researches or practical trials:

- Computer-assisted preschool educational activities may have a promising potential to be integrated with a preschool education program.

- Teachers and prospective teachers need to be informed about the implementation of computer-assisted preschool educational activities.

\section{LIMITATIONS AND RECOMMENDATIONS}

There are some of the limitation of this study which must be addressed in future. The limitations and recommendation for future are:

- The current research is conducted by using an experimental design with small-sized research groups. Further researches may use larger research groups to establish a better observation over computer assisted preschool educational activities.

- New researches may need to investigate the long-term effects of computerassisted preschool educational activities.

\section{REFERENCES}

Akman, Berrin. 2002. Mathematics in preschool. Hacettepe University Journal of Education Faculty 23, 244-248. Aktaş-Arnas, Yaşare. 2005. Okul öncesi dönemde bilgisayar destekli eğitim. Eğitim Araştırmaları Dergisi 20, 36-47. Altınçelik, Bahriye. 2009. İlköğretim düzeyinde öğrenmede kalıcılı̆ı ve motivasyonu sağlaması yönünden akıllı tahtaya ilişkin öğretmen görüşleri. Yayınlanmamış yüksek lisans tezi, Sakarya Üniversitesi, Adapazar, TR.

Aral, Neriman, and Ayhan Bütün. 2004. Bilgisayar destekli eğitim alan ve almayan anaokuluna devam eden çocukların görsel algılamalarının incelenmesi. Paper presented at OMEP Dünya Konsey Toplantısı ve Konferansı, Kuşadası, TR, October 5-11.

Baroody, Arthur J. 1987. Children's mathematical thinking: A developmental framework for preschool, primary, and special education teachers. New York, US: Teachers College, Press.

Berk, Laura E., and Işıkoğlu Erdoğan. 2013. Bebekler ve çocuklar, doğum öncesinden orta çocukluğa. Ankara, TR: Nobel Yayın Dağıtım.

Clements, Douglas H. 1987. Computers and young children: A review of research. Young Children 43, no. 1: 34-44. D0I: 10.2304/ciec.2002.3.2.2

Clements, Douglas H. 2002. Computers in early childhood mathematics. Contemporary Issues in Early Childhood 3, no. 2: 160-181.

Cohen, Rachel. 1995. Do new technologies modify the learning processes for young children?. Paper presented at the 5th European Conference on the Quality of Early Childhood Education, Paris, FR, 7-9 September.

Dixon, James A., and Moore, Colleen F. 1996. The developmental role of intuitive principles in choosing mathematical strategies. Developmental Psychology 32, no. 2: 241-253. D0I: 10.1037/0012-1649.32.2.241

Donaldson, Margaret. 1992. Human minds: An exploration. London, UK: The Penguin Press.

Efendioğlu, Akin. 2006. Anlamlı öğrenme kuramına dayalı olarak hazırlanan bilgisayar destekli geometri programının ilköğretim dördüncü sınıf öğrencilerinin akademik başarılarına ve kalıcılı̆g etkisi. Yayınlanmamış yüksek lisans tezi, Çukurova Üniversitesi, Adana, TR. 
Farnham-Diggory, Sylvia. 1972. Cognitive processes in education. New York, US: Harper.

Gülcü, İsmail. 2014. Etkileşimli tahta kullanımının avantajları ve dezavantajlarına yönelik öğretmen görüşleri. Paper presented at Akademik Bilişim Konferansı, Mersin Üniversitesi, Mersin, TR, 5-7 February.

Gündoğdu, Tolga. 2014. Bir öğretme-öğrenme aracı olarak akıllı tahta. Akademik Sosyal Araştırmalar Dergisi 2, no. 6: 392-401.

Güven, Yıldız. 2001. Sezgisel matematik yeteneği testinin geliştirilmesi. Türk Psikolojik Danışma ve Rehberlik Dergisi 15, no. 2: 23-28.

Güven, Yıldız. 2004. Aile ve öğretmen katılım programlarının 5 yaş grubu çocukların matematiksel sezgilerine etkisi. Marmara Üniversitesi Eğitim Bilimleri Dergisi 19, 85-94.

Güven, Ylldız. 2007. Okulöncesi dönem çocuklarının sezgisel matematik yeteneklerinin incelenmesi. Marmara Üniversitesi Sosyal Bilimler Enstitüsü Dergisi 7, no. 28: 389-395.

Haugland, Susan W. 2003. Selecting developmentally appropriate software. URL: goo.gl/xhdLbu (accessed February 1, 2015).

Higgins, Steve, Gray Beauchamp, and Dave Miller. 2007. Reviewing the literature on interactive whiteboards. Learning, Media and Technology 32, no. 3: 213-225. DOI: 10.1080/17439880701511040

Pekçağlıyan, Nilgün. 1990. Anaokuluna giden altı yaş grubu çocuklarda uygulanan klasik eğitim yöntemleri ile bilgisayar destekli eğitimin karşılaştırmalı olarak incelenmesi. Yayınlanmamış yüksek lisans tezi, Hacettepe Üniversitesi, Ankara, TR.

Piaget, Jean. 1972. Intellectual evolution from adolescence to adulthood. Human Development 15, no. 1: 1-12. D0I: $10.1159 / 000271225$

Preston, Chris, and Lee Mowbray. 2008. Use of smart boards for teaching, learning and assessment in kindergarten science. Teaching Science 54, no. 2: 50-53.

Senemoğlu, Nuray. 2007. Gelişim, öğrenme ve öğretim: Kuramdan uygulamaya. Ankara, TR: Gönül Yayıncılık. Yıldırım, Cemal. 1996. Matematiksel düşünme. İstanbul, TR: Remzi Kitabevi.

Shute, Rosalyn, and John Miksad. 1997. Computer assisted instruction and cognitive development in preschoolers. Child Study Journal 27, no. 3: 237-254.

— This article does not have any appendix. - 